\title{
いか釣漁業の展望
}

\section{和田 雅昭*}

\section{1. はじめに}

著者らの研究グループは, 情報化による沿岸漁業支 援に取り組んでいる。主たる研究シーズはセンサネッ トワークシステムであり, これまでに小型ブイを活用 した海洋環境の定点観測 [1]や小型漁船を活用した水 産資源の移動観測 [2]で成果を挙げている．著者らの 研究グループは, 情報システムを専門とする研究者と 情報デザインを専門とする研究者で構成される点に大 きな特長があり，いち早く水産業にタブレット端末を 導入することで, 海洋環境と水産資源を可視化し, IT 漁業の基礎を築いた。2011年から本格的なIT漁業に 取り組んでいる北海道留萌市では, なまこの資源回復 が実現している[3].

ところで，1993年から2004年までの12年間，著者 はプログラマとして民間企業で自動いか釣機の開発に 携わり，機械化による沿岸漁業支援に取り組んでい た. 1990年代, 3 相の相補PWM出力機能を備えたマ イクロコンピュータが実用化された技術的な背景も手 伝って,ファジー理論や $1 / \mathrm{f}$ ゆぎ理論を採用したエ アコンが流行した. 自動いか釣機の動力もエアコンの 動力と同じ交流モータであり, インバータ制御を行っ ていることから，1/fゆらぎ理論を試験的に自動いか 釣機に実装したことがあった。著者の経験的な感覚で ありデータの裏付けはないものの, 漁船が摇れること のないべタ凩の日よりも, 心地良い程度に漁船が摇れ る凪の日の方が, 漁獲が良いと感じていたためであ る.いか釣漁業は擬䬣針を小魚に見せかけることで, いかを騙して釣上げる漁法であり，漁船の自然な摇れ が擬䬣針に伝わり，より小魚のように見える動きをす るためではないかと考えていた，残念ながら，著者の

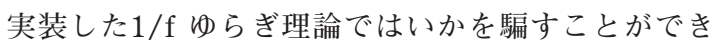
ず, 漁獲の向上につながらなかったことから, 採用は 見送られた。しかしながら，日本知能情報ファジィ学 会の皆様であれば，いかを騙すことができるのではな

$\dagger$ Prospects of the future squid fishing Masaaki WADA

* 公立はこだて未来大学

Future University Hakodate
いだろうか.

自動いか釣機は函館発祥の技術であり，世界市場 シェアの約 7 割を占めている。本報では, 日本が世界 に誇る自動いか鈞機と美しい漁火の下で営まれている いか釣漁業を紹介し, 将来のいか釣漁業を展望する。

\section{2. いか釣漁業}

\section{1 いか釣漁業の概要}

北海道では毎年 6 月から翌年 1 月までの期間に道 内・道外の小型いか釣漁船による沿岸いか釣漁業が営 まれている。農林水産省の統計情報によると，2012年 の北海道の沿岸いか釣漁業の漁獲量は26,153トンであ り, 全国の約 3 分の 1 を占めている(図 1 )。このよう に, 沿岸いか釣漁業は北海道の主要な水産業のひとつ であるが, 図 1 に示すように漁獲量は減少傾向にあ る. 2012年には1996年の半分以下にまで減少した。

いか釣漁業は世界で最も機械化の進んだ漁業であ る.いか釣漁船は30トン未満の小型いか釣漁船(図 2), 185トン以上の大型いか釣漁船, その間に位置する中 型いか釣漁船に分類することができるが，いずれも自 動いか釣機で漁獲している．2013年漁業センサス（農 林水産省)によると, 全国で3,554隻の小型いか釣漁船 が沿岸いか釣漁業を営んでいる. 小型いか釣漁船には 10数台の自動いか釣機が搭載されており, その多くは 1 人乗りである.

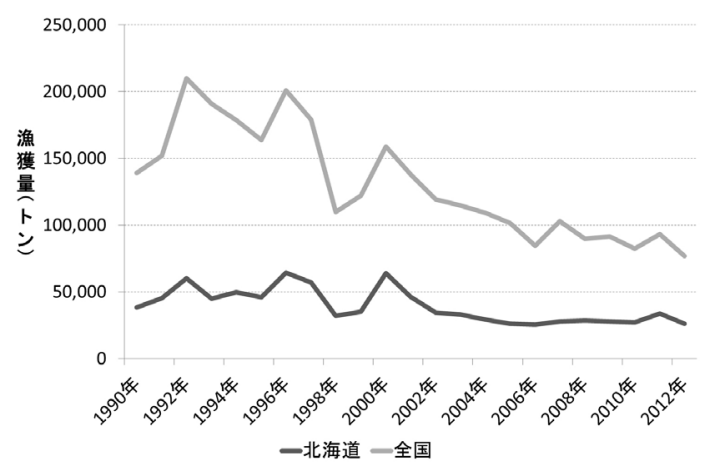

図 1 沿岸いか釣漁業の漁獲量の推移 


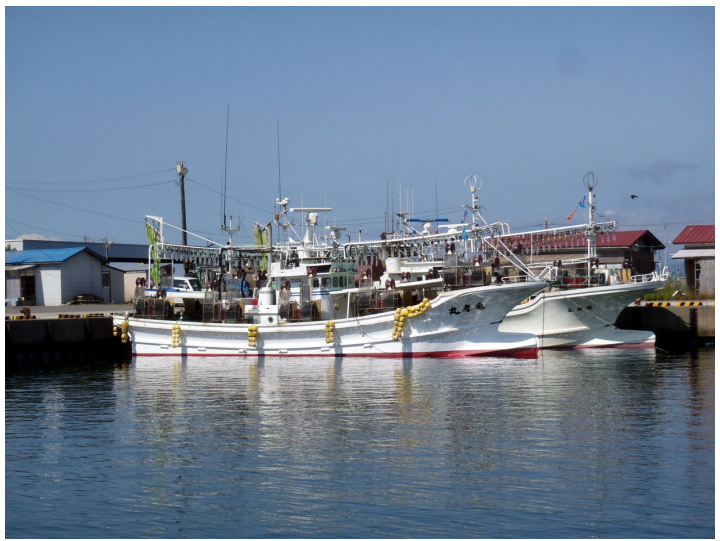

図 2 函館漁港の小型いか釣漁船

\section{2 自動いか釣機}

自動いか釣機は左右にドラムを持ち, 左右のドラム には，それぞれ100〜200mのワイヤが巻かれている. その先に 30 本の擬䭅針がテグスにより $1 \mathrm{~m}$ 間隔で連結 され(図 3 ), 終端に鍾が取りつけられている。自動い か釣機のドラムは交流モータで駆動しており, ワン ウェイクラッチを採用していることから，モータの駆 動力は巻上げにの及作用し, 巻下げには作用しない. 巻下げは重力を利用している。自動いか釣機は設定し た水深まで巻下げ, 海面まで巻上げるという一連の動 作を繰り返す。函館沿岸では, 浅いときは $60 \mathrm{~m}$ 程度, 深いときは $120 \mathrm{~m}$ 程度に水深を設定している。自動い か釣機に卷かれたワイヤは水平に繰り出され，漁船の 両船に張り出した前ローラと呼ばれる滑車で鉛直に向 きを変える，擬䬣針にはかえしがないことから，釣上 げられたいかは前ローラを通過するタイミングで跳ね るように擬飭針から外れる(図4)。

自動いか釣機のドラムは, 従来は菱形ドラムが利用 されていたが，現在は丸型ドラムが主流になってい る.自動いか釣機は，擬䬣針を小魚に見せかけるた め，強弱をつけてドラムを回転させるシャクリと呼ば れる動作を行う。そのため, 強いシャクリをつくるこ とができる菱形ドラムを漁業者は好んで利用してい た。しかしながら，近年はマイクロコンピュータの発 達により高度なモータ制御が可能になったことから， 丸型ドラムを用いて菱形ドラムと同等の強いシャクリ をつくることができるようになった，丸型ドラムは菱 形ドラムに比べて, 巻下げ時にワイヤがふけにくい,

ドラムの位置合わせが不要になるといった利点がある ことから，漁業者は好んで丸型ドラムを利用するよう になった。な打，菱形ドラムも丸型ドラムも外周は $1.32 \mathrm{~m}$ である。

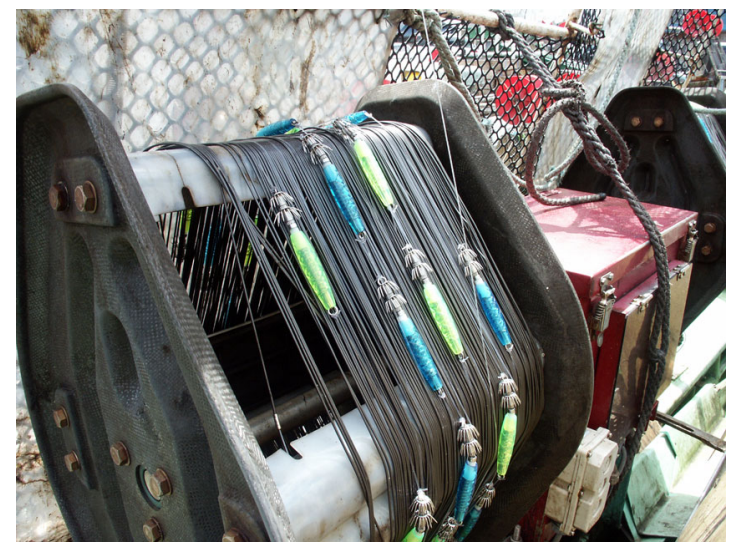

図 3 ドラムに巻かれた擬餌針

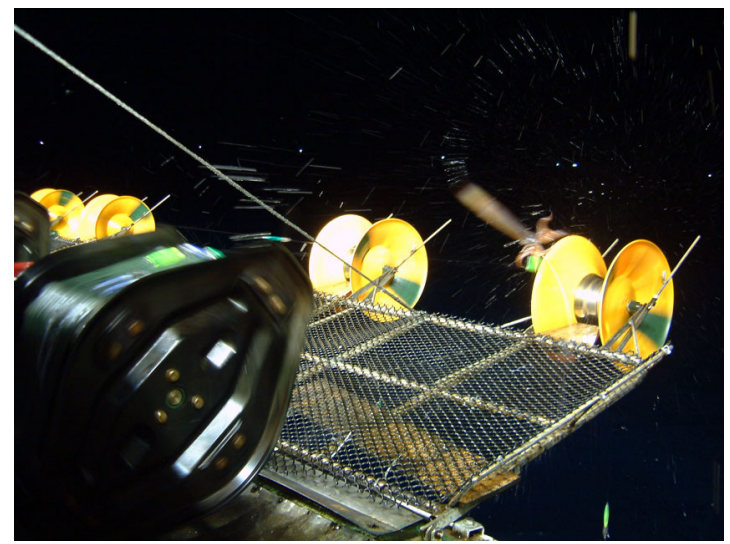

図 4 擬餌針から外れるいか

\section{3 いか釣漁業の漁法}

いかは強い光を避ける習性があり, 昼間は太陽光の 届かない深層に移動し, 夜間は表層に移動する。いか 釣漁業では 1 時間あたりの巻下げ, 巻上げの回数が効 率の指標とされることから, 効率の良い夜間にいか釣 漁業が営まれている。なお，集魚灯の役割は直接的に いかを集めることではなく, 間接的にいかを集めるこ とである。すなわち, 漁船の周囲を集魚灯で照らすこ とによって, 船底に陰影をつくり, 集魚灯の光を避け て船底の陰影に集まったいかを釣上げている $[4]$.

沿岸いか釣漁業では1996年以降, 集魚灯の光力を $180 \mathrm{~kW}$ 以下する自主規制を設けた。 1 灯あたりの 光力は $3 \mathrm{~kW}$ あることから, 小型いか釣漁船には最 大で60灯の集魚灯が並んでいる(困 5 )。 なお, 集魚灯 の主流は現在もメタルハライドランプである. LED集 魚灯の開発も進んでいるが, 光の直進性が強く広範囲 を照らすことが難しいため, 船底にいかを集めること ができず普及していない。 


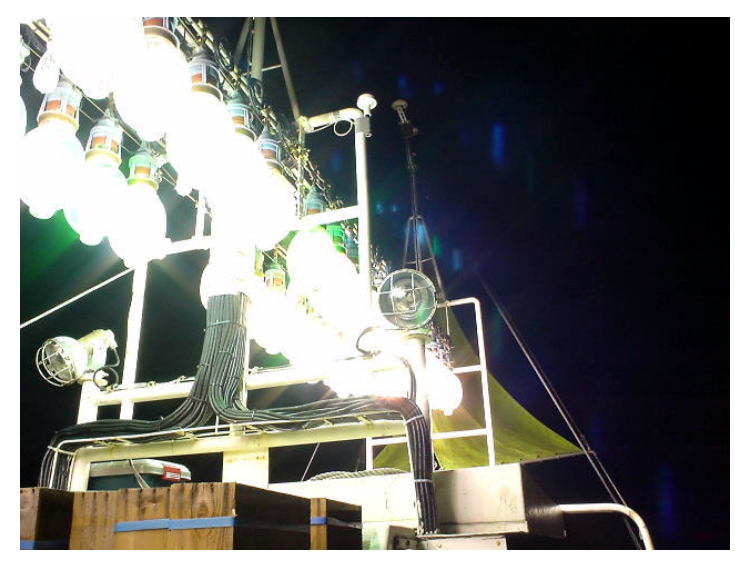

図 5 集魚灯（メタルハライドランプ）

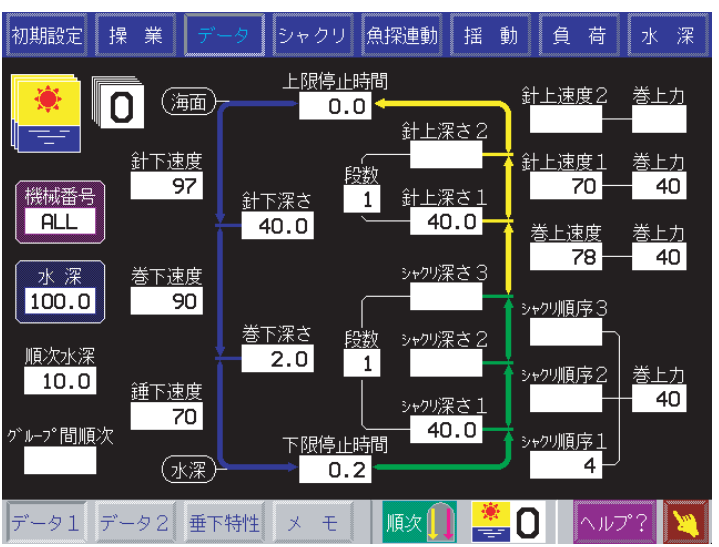

図 6 集中制御盤のデータ設定画面

\section{4 集中制御盤}

小型いか釣漁船に搭載された10数台の自動いか釣機 とブリッジに設置された 1 台の集中制御盤はRS485の 半二重回路で接続されており, 集中制御盤がすべての 自動いか釣機を管理している。自動いか釣機には100 を超えるパラメータがあり, 集中制御盤で設定するこ とができる。図 6 にデータ設定画面を示す，反時計回 りに巻下げ, 巻上げのパラメータが配置されている. 巻下げ，巻上げともに海面から設定水深までの深さを 3 分割して設定することができる。速度の単位はドラ ムの回転数 $(\mathrm{rpm})$ であり, 80 回転は $1.76 \mathrm{~m} / \mathrm{sec}$ に相当 する。また，深さの単位はメートルである。

\section{5 シャクリ}

自動いか釣機の100を超えるパラメータのなかで, もっとも漁獲に影響を及ぼすパラメータはシャクリの パラメータである。その設定值は秘匿情報として取り 扱われており，漁業者から聞き出すことはほぼ不可能

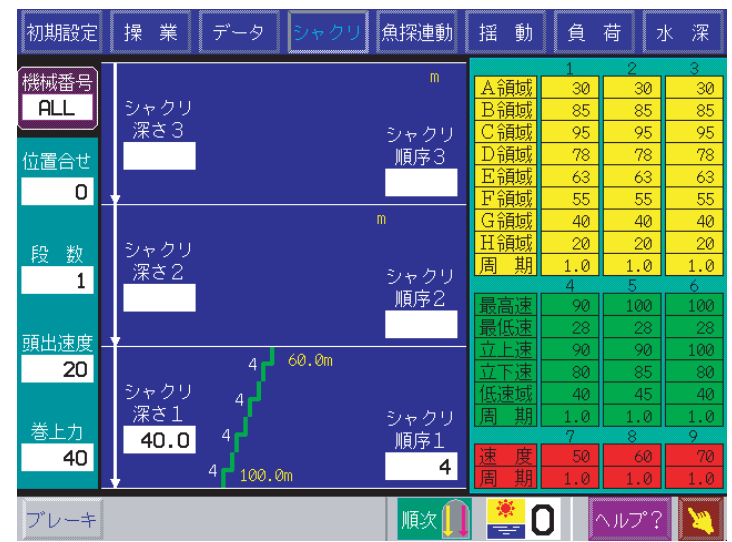

図 7 集中制御盤のシャクリ設定画面

である。罒7 にシャクリ設定画面を示す。シャクリは 大きく 2 種類に分けることができる. 1 つは 8 等分 シャクリであり，もう1つは強弱シャクリである.

8 等分シャクリはドラムの 1 回転を 8 つの領域に等 しく分割し, 各領域の回転数を設定することで, ドラ ムの回転に強弱をつける。一方, 強弱シャクリはドラ ムの 1 回転を高速領域と低速領域の 2 つの領域に分割 し, 各領域の回転数と比率を設定することでドラムの 回転に強弱をつける。8等分シャクリ, 強弱シャクリ はそれぞれ3つまで登録することができ，自由に組み 合わせて動作させることができる。

著者は $1 / \mathrm{f}$ ゆぎ理論に基づいて 8 等分シャクリの パラメータをダイナミックに書き換えるプログラムを 試験的に実装し, 複数の小型いか釣漁船で評価を行っ た. 少なくとも当時は, 漁業者が勘と経験に基づいて パラメータを調整したシャクリに勝ち目はなかった。

\section{6 負荷検出}

自動いか釣機の動力は前述のとおり交流モータであ り，センサレスベクトル制御を行っている。計測した 負荷電流は，釣上げているいかの数に換算することが できる。罒8 に負荷表示画面を示す，罒8 の例ではい か釣漁船の両䑪に各 4 台, 計 8 台の自動いか釣機が搭 載されている. 自動いか釣機の運転状況はアイコン， ならびに, 棒グラフによってリアルタイムで把握する ことができる．棒グラフは 2 段で表示され，幅の狭い 上段が現在水深を，幅の広い下段が釣上げているいか の数を示している. 右舷の 1 号機がいかを釣上げてい ることがわかる. 


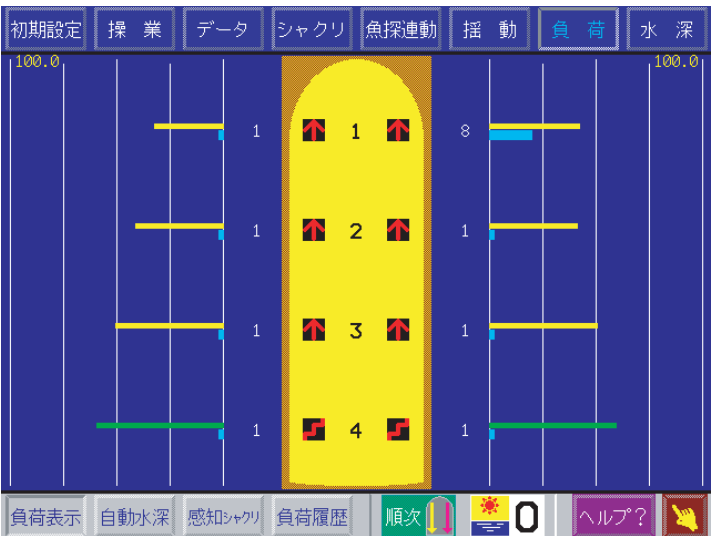

図 8 集中制御盤の負荷表示画面

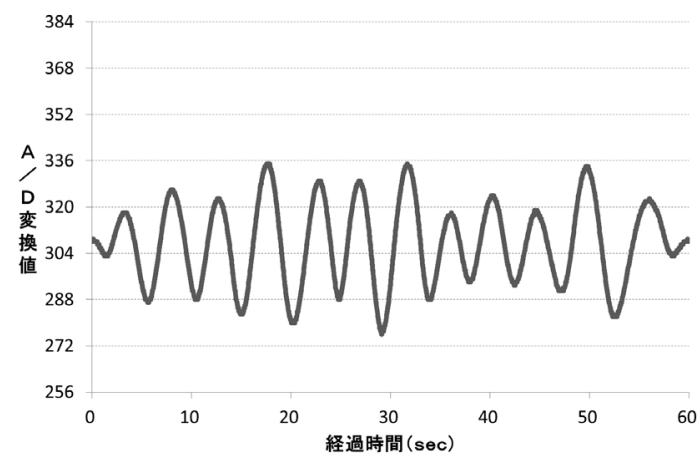

図 9 大型いか釣漁船で計測した加速度

\section{7 いか釣漁船の船体運動}

いか釣漁船は船首から海中にパラシュートアンカー を投入し, 船尾にスパンカーと呼ばれる帆を立てるこ とで, 船体を安定させている，そのため, 船体運動は pitching とheavingが支配的となる。図 9 に著者が 1 軸の加速度センサを用いて, 大型いか釣漁船の船首に 搭載した自動いか釣機で計測した加速度を示す。計測 に用いた加速度センサの仕様は, 電源電圧が $5.0 \mathrm{~V}$, 才 フセット電圧が $2.5 \mathrm{~V}$, 感度が $1,000 \mathrm{mV} / \mathrm{g}$ である。ま た，ここでは10bit のA/D変換器を用いて $100 \mathrm{~Hz}$ のサ ンプリング周期で計測し，11段のFIRフィルタを適用 したものを $\mathrm{A} / \mathrm{D}$ 変換值としている。加速度の周期は約 4.1秒である。 また， $\mathrm{A} / \mathrm{D}$ 変換值の最大は 335 ，最小は 276 であり，それぞれ $0.13 \mathrm{~g} ，-0.16 \mathrm{~g}$ に相当する。

従来は, 時化の日の漁獲は凪の日の漁獲に比べて明 らかに悪かった。擬䬣針に掛かったいかは一定速度で 巻上げると逃げることができないが，速度が変化しワ イヤがふけると擬䬣針にはかえしがないことから簡単
に逃げることができる．時化の日は自動いか釣機の 巻上げ速度に船体運動による速度が合成されること から，巻上げ速度が一定とならず，ワイヤがふける ことによっていかが逃げ, 漁獲が悪くなる。

仮に船体運動が振幅 $0.16 \mathrm{~g}$, 周期 4.1 秒の正弦波に同 期しており，自動いか釣機が80回転で巻上げている とした場合には, 船体運動による速度は最大で $1.02 \mathrm{~m} / \mathrm{sec}$ となり，巻上げ速度は $1.76 \mathrm{~m} / \mathrm{sec}$ 中心に $0.74 \mathrm{~m} / \mathrm{sec}$ か $2.78 \mathrm{~m} / \mathrm{sec} の$ 範囲で変化する。この值 は，ワイヤがふけるには十分な值である。現在は， 加速度センサが自動いか釣機に標準で装備されてい る.自動いか釣機は検出した船体運動にあわせて巻 上げ速度を調整することでワイヤのふけを防止して おり, 時化の日の漁獲と咸の日の漁獲に差はなく なっている。

\section{3. いか釣漁業の展望}

\section{1 漁獲の可視化}

著者らの研究グループは, 北海道留萌市のなまこ 桁網漁船全16隻の位置情報を対象としたセンサネッ トワークシステムを構築している。眓10は収集した なまこ桁網漁船の位置情報を用いて, 現在の位置と 航跡を独自に開発したiPadアプリケーション「マリン プロッタ」で表示したものである。なまこ桁網漁業で は，桁網と呼ばれる漁具を投網し， $4 \mathrm{~km} /$ hour 程度の ゆっくりとした速度で約 1 時間曳網したあと, 揚網 するという一連の作業を繰り返す。いか釣漁業とは 異なり機械化されていないことから, 漁業者の協力 を得て漁獲情報を収集している。四11は漁獲情報を 収集するために独自に開発したiPadアプリケーショ ン「デジタル操業日誌」である。漁業者は 1 曳航あた り 3 回の入力を行う. 投網と揚網はタップすると, そのときの時刻が自動的に入力される。また, 曳網 時間を意味する投網時刻と揚網時刻の差は, 自動的 に計算され表示される。そして，漁獲したなまこを 選別したあと，漁獲をタップしテンキーで漁獲量を 入力する。なお, 漁獲量の単位は樽である。

なまこ析網漁船の位置情報には緯度経度に加えて 日付時刻が含まれていることから，操業情報を用い ることで曳網の航跡を抽出することができる。漁場 の管理は $100 \mathrm{~m} \times 100 \mathrm{~m}$ のグリッドを単位としており， 曳網したグリッド数で漁獲量を按分することによ り，グリッド毎の漁獲量を求めることができる。ま た, グリッド毎の資源量を推定することもでき, 全 グリッドの資源量の総和が漁場全体の推定資源量と なる。困12はグリッド毎の漁獲量を可視化したもの である。 


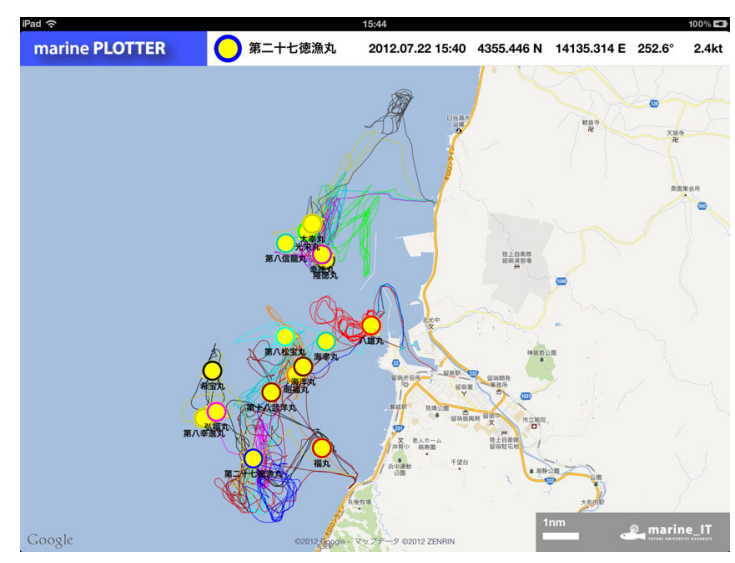

図 10 小型漁船のリアルタイムモニタリング

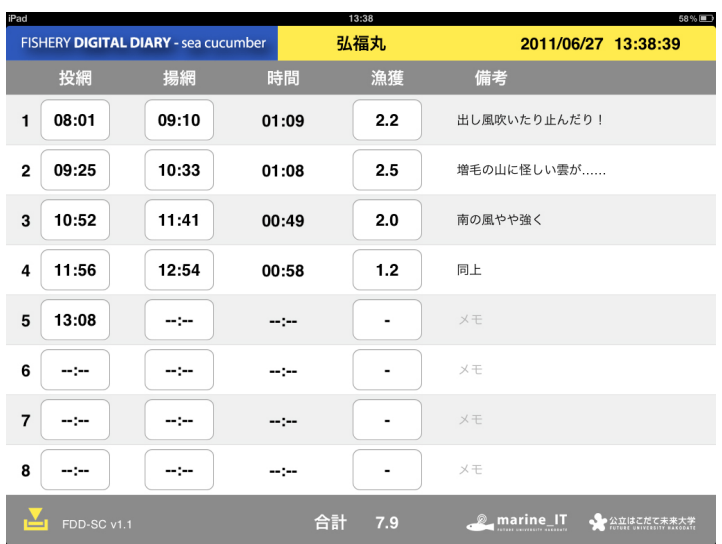

図 11 漁獲情報を収集する $\mathrm{iPad}$ アプリケーション

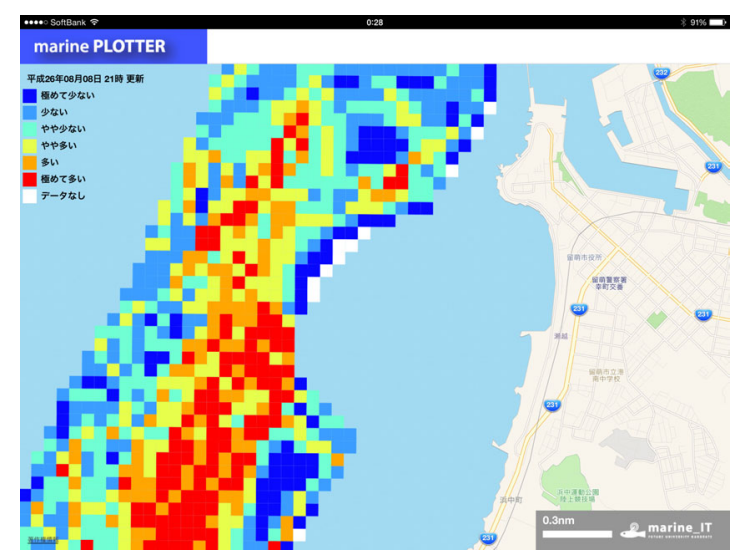

図12 漁獲量の可視化

なお，位置情報には速度と進路も含まれており，航 跡を解析することで曳網したグリッドを抽出すること も可能である.
いか釣漁業では, 前述のように自動いか釣機が負荷 を検出していることから, 漁獲情報を自動で収集する ことができる。ささらに，いかが釣れた水深がわかるこ とから，三次元のグリッドで漁場を管理することが可 能となる。このように機械化が進んでいるいか釣漁業 は，もっとも情報化を推進しやすい漁業であるが, 位 置情報, 漁獲情報は秘匿情報とされており, 情報の共 有が図られていない。しかしながら，2003年漁業セ ンサス(農林水産省)によると, 全国の小型いか釣漁船 数は5,395隻であり，10年間で約 3 分の 2 に減少して いる．持続可能ないか釣漁業を推進するためには情報 の共有は不可欠であり, 著者らの研究グループは沿岸 いか釣漁業, ならびに, 近海いか釣漁業の情報化に取 り組んでいる.

\section{2 漁場の可視化}

いかの漁場形成は中層水温と関係が深いことが知ら れている $[5]$ 。また, 索䬣期, ならびに, 成長期のい かが分布する水温条件は下限が $12^{\circ} \mathrm{C}$, 上限が $23^{\circ} \mathrm{C}$ と されている [6]. 北海道では水産試験場の 3 隻の試験 調査船が定期的に海洋観測機器を用いて鉛直水温を観 測しているが, 観測回数は年 6 回, 観測点数は 179 点 と限られていることから, いかの漁場を可視化するた めには時空間的な観測密度の向上が必要である。そこ で，いか釣漁船による鉛直水温の観測が実現すれば， 観測密度が飛躍的に向上し, 漁場の可視化が可能にな ると考えられる.

著者らの研究グループは, 漁業者が容易に操作する ことのできる簡易型海洋観測機器の開発に取り組んで いる。簡易型海洋観測機器には水深を計測するための 圧力七ンサと水温を計測するための温度センサ，なら びに, 通信のための Bluetooth モジュールが装備され ている。簡易型海洋観測機器をワイヤに吊るし, $1 \mathrm{~m} /$ $\sec$ 程度の速度で巻下げると $1 \mathrm{~m}$ 毎に水温を計測しメ モリに記録する。そして, 海面まで巻上げたのち, メ モリに記録した水温をタブレット端末に転送する。図13 は試作した簡易型海洋観測機器を用いて2014年 6 月 27日に観測した九十九湾(石川県)の鉛直水温のグラフ である。この海域では, いかは水深 $120 \mathrm{~m}$ 以浅に分布 しているものと考えられる。

なお, 試作した簡易型海洋観測機器の形状は外径が $50 \mathrm{~mm}$, 長さが $175 \mathrm{~mm}$ の円柱型であり, 体積は $344 \mathrm{~cm}^{3}$ となっている. 将来的には, 自動いか釣機で利用され ている錘 $\left(300\right.$ 号, 約 $1.1 \mathrm{~kg}$ )の体積である $160 \mathrm{~cm}^{3}$ を目 標として小型化を図り，錘に置き換えることによって 観測を自動化する計画である. 鉛直水温もまた三次元 のグリッドで管理することができ, 情報を共有するこ 


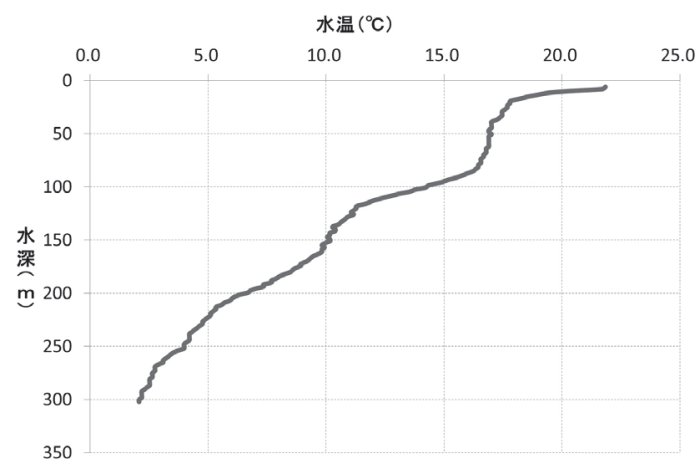

図13 九十九湾の鉛直水温グラフ

とで漁獲量と水温の関係から, いかの漁場形成の条件 が明らかとなる。さらには，明日，明後日の漁場予測 も可能になると考えられる.

\section{4. おわりに}

本報では，世界で最も機械化の進んだ漁業であるい か釣漁業を紹介した。扣そらく，半分以上の読者が集 魚灯の役割を誤解されていたのではないだろうか. せっかくの機会であるので，もう少しあまり知られて いない情報を提供したい。いかの寿命は 1 年であり， 耳石に相当する平衡石に日周輪が 1 日 1 本形成される [7]，そのため，いかの誕生日を知ることができる. また，いかは魚群探知機に反応しないことから，いか の群れを探すことは困難である．魚群探知機に反応す るのは魚の鰾(うきぶくろ)であり［8，いかは鰾を持 たないことから反応しない，

さて，本題である．持続可能ないか釣漁業を推進す るためには, 著者らの研究グループが取り組む情報化 に加えて，コスト削減のための省エネルギー化が不可 欠である. 現在, 集魚灯の主流はメタルハライドラン プであり，LED集魚灯は普及していない，しかしなが ら，LED集魚灯の燃料消費量はメタルハライドランプ のわずか 100 分の 6 であり [9]，LED集魚灯の普及に より大きな省エネルギー効果が得られる.

LED集魚灯を普及させるためには，メタルハライド ランプとは異なる使い方で，いかを集める必要があ る. LEDは自由に調光, 調色することができる。その 特長を活かし，農業では植物工場における栽培実験に より，LEDを連続光ではなくパルス光として照射する ことによって植物の成長率, 光合成速度が増大するこ とが確認されている $[10]$. 同様に，いか釣漁業におい てもLEDの欠点を補うのではなく, LEDの利点を活 かすことが重要であり，例えば，LED集魚灯を調光，
調色することでいかを船底に誘うなど, 直接的にいか を集めることも可能ではないかと考えている.

また，集めたいかを効率的に漁獲することができれ ば，自動いか釣機の稼働時間の短縮による省エネル ギー化が実現する。これには2つの方法が考えられ る. ひとつは, 漁業者の勘と経験に基づくシャクリよ りもいかが騙されやすい自動いか釣機の動作を考案す

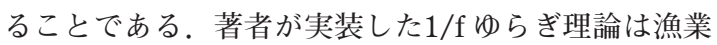
者のシャクリに惨敗であった。しかしながら，ファ ジー理論や $1 / \mathrm{f}$ ゆゔ理論に限る必要はないが，日本 知能情報ファジィ学会の皆様であれば, 漁業者のシャ クリと対等に渡り合える， あわよくば超えることので きる新しい動作を考案していただけるのではないかと 期待している.

もうひとつは，できるだけ海面近くにいかを集める ことである. 設定水深が浅いほど, 1 時間あたりの巻 下げ, 巻上げの回数が増えることから効率的な漁獲が 可能になる。エアコンの空調をコントロールすること で，ひとにとって心地の良い空間をつくりだす技術を 応用すれば，LED集魚灯の光と色をコントロールする ことで，いかにとって心地の良い空間をつくりだすこ とも可能ではないかと考えている.

総務省の家計調査によると, いかは 1 世帯当たりの 購入数量が第 2 位の魚介類であり, 日本人はいか好き である。もし，いかが好きでないという読者がいらっ しゃるとすれば，それは本場のいかを食べたことがな いからではないだろうか. 是非, 函館に足を運んでい ただき, 漁業者が日本一と認める函館のいか(図14)を 味わっていただきたい。そして，いか釣漁業を変革す る打知恵を賜れば幸甚である。

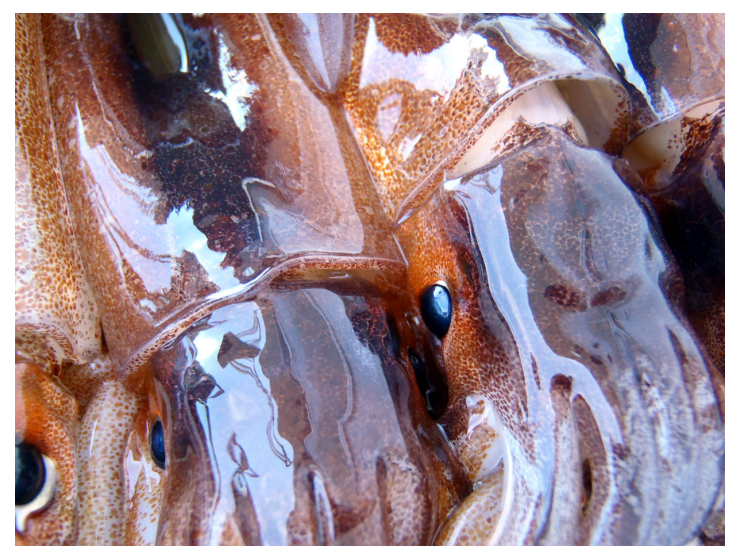

図14函館の朝いか 


\section{参 考 文 献}

［1］和田雅昭, 畑中勝守, 戸田真志, 養殖漁業支援のため のユビキタスブイの開発, 情報処理学会論文誌, Vol.49, No.6, pp.1833-1843, 2008

[2] 佐野稔, 前田圭司, 高柳志朗, 和田雅昭, 畑中勝守, 本前伸一, 菊池肇, 宮下和士, 漁業情報を用いた北海 道北部沿岸域に打けるマナマコの資源量推定, 日本水 産学会誌, Vol.77, No.6, pp.999-1007, 2011

[ 3 ] 和田雅昭, ユビキタスネット社会に打ける水産業, 信 学技報, Vol.113, No.186, pp.35-38, 2013

４］＼cjkstart四方崇文, 島敏明, 稲田博史, 三浦郁男, 臺田望, 貞 安一廣, 渡部俊広, イ力釣り操業時に船上灯光により 形成される船底下陰影部のスルメイカの誘集・漁獲過 程に打ける役割, 日本水産学会誌, Vol.77, No.1, pp.5360,2011

５］四方崇文, 広瀬直毅, 日本海沖合に打けるスルメイカ 漁場の探索と予測，スルメイカ資源評価協議会報告， pp. $25-28,2010$

[6] 桜井泰憲, 森賢, 後藤常夫, 木所英昭, 山本潤, スル メイカ, 水産海洋シンポジウム講演要旨集, 2007

[ 7 ] 坂口健司, 中田淳, 2001年の北海道北部海域における
スルメイカの日歯令と群構造, 海洋水産研究, Vol.70, No.1, pp.16-22, 2006

［8］板谷和彦, 浅見大樹, 高嶋孝寛, 仙法志堆（利尻島南 西部）におけるホッケの計量魚探調查, 北水試だよ り, Vol.84, pp.6-9, 2012

［9］四方崇文, 山下邦治, 白田光司, 町田洋一, 日本海沖 合漁場におけるイ力釣り漁業用青色 LED 漁灯の性能 評価, 日本水産学会誌, Vol.78, No.6, pp.1104-1111, 2012

[10］森康裕, 高辻正基, 安岡高志, 白色 LED パルス光が サラダナ生育に及ぼす影響, 植物工場学会誌, Vol.14, No.3, pp.136-140, 2002

（2015年 3 月 5 日 受付）

[問い合わせ先］

干041-8655 北海道函館市龟田中野町116-2

公立はこだて未来大学

和田 雅昭

TEL : 0138-34-6412

FAX : 0138-34-6301

E-mail : wada@fun.ac.jp

\section{著者紹 介}

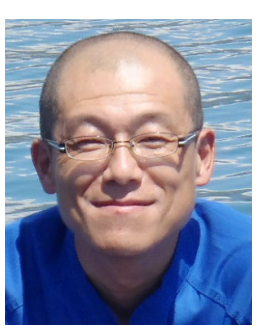

\section{杂态散雅暗 $[$ 非会員]}

公立はこだて未来大学システム情報

科学部情報アーキテクチャ学科教授.

同大学マリンIT・ラボ所長. 専門は水 産情報学. 1971年, 静岡県焼津市の生 まれ, 宮城県仙台市の育ち。1993年, 北海道大学水産学部卒業. 2004年, 北海道大学大学院水産科学研究科修 了. 博士(水産科学). 株式会社東和電 機製作所を経て，2005年，公立はこだ て未来大学に着任。2012年より現 職. 日本航海学会, 情報処理学会, 電 子情報通信学会, IEEEの会員. 平成 24 年度北海道科学技術賞, 平成 26 年 度北海道総合通信局長表彰，平成 26 年度近畿運輸局長表彰を受賞. 函館イ カマイスター。 